\title{
Rho-Kinase Accelerates Synaptic Vesicle Endocytosis by Linking Cyclic GMP-Dependent Protein Kinase Activity to Phosphatidylinositol-4,5-Bisphosphate Synthesis
}

\author{
Zacharie Taoufiq, ${ }^{1 *}$ Kohgaku Eguchi, ${ }^{1 *}$ and Tomoyuki Takahashi ${ }^{1,2}$ \\ ${ }^{1}$ Cellular and Molecular Synaptic Functional Unit, Okinawa Institute of Science and Technology Graduate University, Onna-son, Okinawa 904-0495, Japan, \\ and ${ }^{2}$ Laboratory of Molecular Synaptic Function, Doshisha University Graduate School of Brain Science, Kyotanabe, Kyoto 610-0394, Japan
}

Rho-kinase plays diverse roles in cell motility. During neuronal development, Rho-kinase is involved in neuronal migration, and in neurite outgrowth and retraction. Rho-kinase remains highly expressed in mature neurons, but its physiological roles are poorly understood. Here we report that Rho-kinase plays a key role in the synaptic vesicle recycling system in presynaptic terminals. Vesicles consumed by excessive exocytosis are replenished by accelerating vesicle endocytosis via a retrograde feedback mechanism involving nitric oxide released from postsynaptic cells. This homeostatic control system involves presynaptic cyclic GMP-dependent protein kinase (PKG) and a plasma membrane phospholipid, phosphatidylinositol-4,5-bisphophate $\left(\mathrm{PIP}_{2}\right)$. We found that application of a Rho-kinase inhibitor, a PKG inhibitor or both, reduced the PIP ${ }_{2}$ content in Wistar rat brainstem synaptosomes to a similar extent. Likewise, application of the Rho-kinase inhibitor into the calyx of Held presynaptic terminal slowed vesicle endocytosis to the same degree as did application of the PKG inhibitor. This endocytic slowing effect of the Rho-kinase inhibitor was canceled by coapplication of PIP ${ }_{2}$ into the terminal. By contrast, a RhoA activator increased the $\mathrm{PIP}_{2}$ content and reversed the effect of the PKG inhibitor in brainstem synaptosomes. The RhoA activator, when loaded into calyceal terminals, also rescued the endocytic slowing effect of the PKG inhibitor. Furthermore, intraterminal loading of anti-PIP ${ }_{2}$ antibody slowed vesicle endocytosis and blocked the rescuing effect of the RhoA activator. We conclude that Rho-kinase links presynaptic PKG activity to PIP $_{2}$ synthesis, thereby controlling the homeostatic balance of vesicle exocytosis and endocytosis in nerve terminals.

\section{Introduction}

At chemical synapses, an action potential arriving at the nerve terminal induces $\mathrm{Ca}^{2+}$ influx into the cell, thereby triggering exocytic release of neurotransmitter by fusion of synaptic vesicle membranes into the plasma membrane of the terminal. After releasing neurotransmitter, vesicle membrane is retrieved from the plasma membrane by endocytosis, and new vesicles are reformed and refilled with neurotransmitter to be reused in another round of synaptic transmission (Schweizer and Ryan, 2006; Jung and Haucke, 2007; Royle and Lagnado, 2010).

Clathrin-mediated endocytosis is a major vesicle-recycling pathway (Granseth et al., 2006; Jung and Haucke, 2007; Dittman and Ryan, 2009; Haucke et al., 2011). In clathrin-mediated endo-

\footnotetext{
Received Feb. 18, 2013; revised June 11, 2013; accepted June 14, 2013.

Author contributions: Z.T. and T.T. designed research; Z.T. and K.E. performed research; Z.T., K.E., and T.T. analyzed data; Z.T., K.E., and T.T. wrote the paper.

This work was supported by the Core Research for Evolutional Science and Technology program of the Japan Science and Technology Agency to T.T. and the Japanese Ministry of Education, Culture, Sports, Science and Technology Grant-in-Aid for Young Scientists to K.E. We thank Steven D. Aird for editing this manuscript and MichaelC. Roy for technical assistance.

The authors declare no competing financial interests.

*Z.T. and K.E. contributed equally to this work.

Correspondence should be addressed to either Dr. Zacharie Taoufiq or Dr. Tomoyuki Takahashi, Cellular and Molecular Synaptic Functional Unit, Okinawa Institute of Science and Technology Graduate University, 1919-1 Tancha, Onna-son, 0kinawa 904-0495, Japan. E-mail: zacharie.taoufiq@oist.jp or ttakahas@oist.jp.

DOI:10.1523/JNEUROSCI.0730-13.2013

Copyright $\odot 2013$ the authors $\quad 0270-6474 / 13 / 3312099-06 \$ 15.00 / 0$
}

cytosis, the adaptor protein complex 2 binds to clathrin, synaptotagmin, and stonin 2, together with phosphatidylinositol-4,5bisphophate $\left(\mathrm{PIP}_{2}\right)$ in the plasma membrane, to promote clathrin coat formation (McPherson et al., 1996; Jost et al., 1998; Itoh et al., 2001; Dittman and Ryan, 2009; Royle and Lagnado, 2010; Haucke et al., 2011). PIP 2 is also thought to be involved in clathrin uncoating (Cremona et al., 1999). Furthermore, PIP $_{2}$ binds to the GTPase dynamin, possibly assisting tubular invagination and vesicle formation (Zheng et al., 1996). At hippocampal synapses in culture (Micheva et al., 2003) and at calyx of Held synapses in rodent brainstem slices (Eguchi et al., 2012), retrograde activation of cyclic GMP-dependent protein kinase (PKG) by nitric oxide (NO) released from postsynaptic cells accelerates vesicle endocytosis by elevating the level of $\mathrm{PIP}_{2}$ in the presynaptic terminal. However, it is not known how PKG is linked to $\mathrm{PIP}_{2}$.

Rho-kinase is a coiled-coil-forming serinelthreonine protein kinase and a major effector of the small GTPase RhoA. Rhokinase is involved in cell motility, such as migration and proliferation, as well as in cell survival (Riento and Ridley, 2003; Mueller et al., 2005). In neurons, Rho-kinase contributes to neurite outgrowth (Bito et al., 2000) and neurite retraction (Nakayama et al., 2000; Riento and Ridley, 2003; Mueller et al., 2005; Sunico et al., 2010). At synapses, Rho-kinase activity reportedly participates in transmitter release (González-Forero et al., 2012) and in presynaptic plasticity (Ota et al., 2010). The NO/PKG signaling cascade upregulates RhoA expression in vascular tissue 

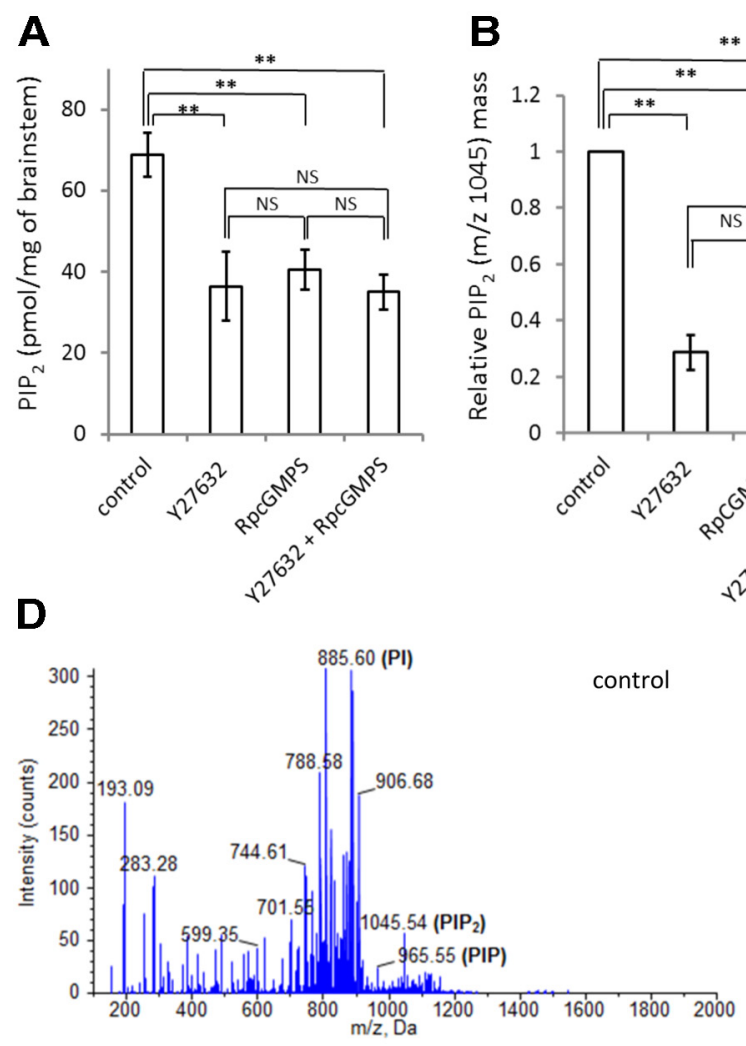

B

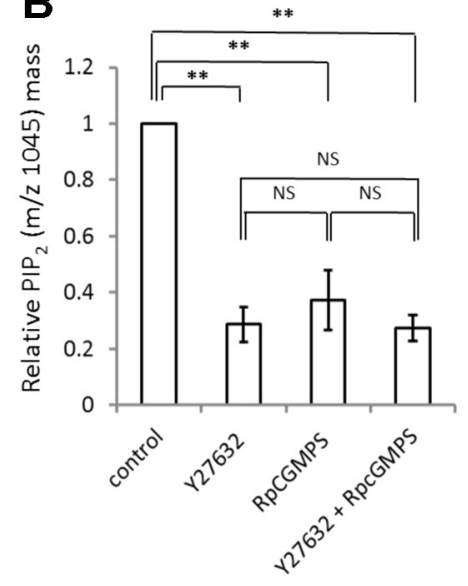

C

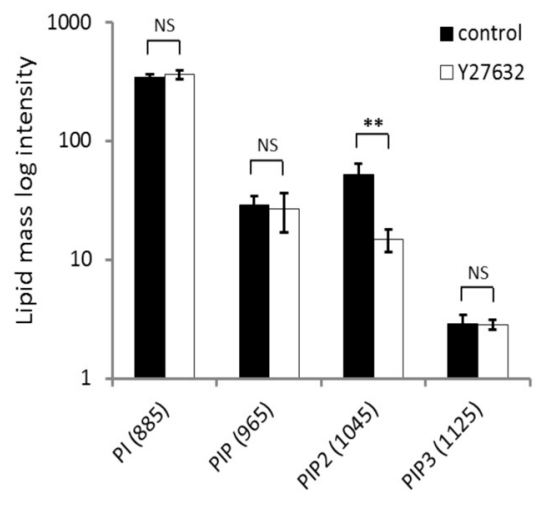

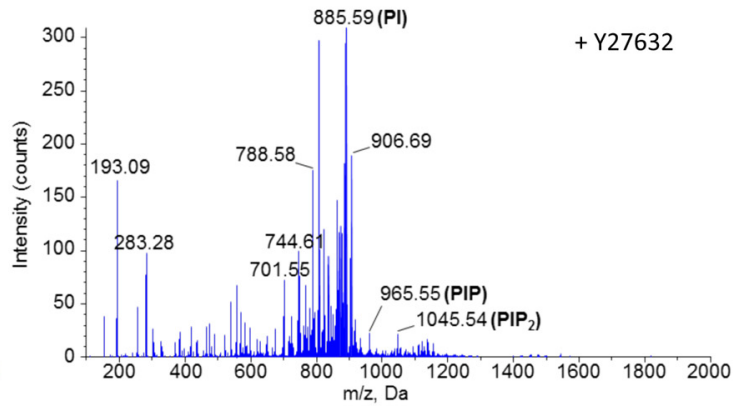

Figure 1. Rho-kinase inhibitor decreased PIP level in brainstem synaptosomes. $\mathrm{PI}(4,5) \mathrm{P}_{2}$ levels in brainstem synaptosomes assayed using ELISA $(\boldsymbol{A})$ and tandem mass spectrometry $(\boldsymbol{B})$. Brainstem tissue was incubated with Y27632 $(4 \mu \mathrm{M})$ or/and with Rp-CGMPS $(3 \mu \mathrm{M})$ for 15 min at $37^{\circ} \mathrm{C}$. C, The inhibitory effect of $\mathrm{Y} 27632(4 \mu \mathrm{M})$ on the levels of PI, PIP, PIP 2 , and PIP ${ }_{3}(\mathrm{~m} / \mathrm{z} 885$, 965 , 1045 , and $1125 \mathrm{Da}$, respectively) assayed using tandem mass spectrometry. $\boldsymbol{D}$, Representative mass spectrometry profiles of acidic lipids from rat brainstem synaptosomes control and Y27632treated tissues $(n=6)$. NS, not significant. ${ }^{* *} p<0.01$.

(Sauzeau et al., 2003). In cell lines, RhoA reportedly enhances production of $\mathrm{PIP}_{2}$ from PIP, by activating phosphatidylinositol5-phosphate kinases (PIP5K) (Shibasaki et al., 1997; Weernink et al., 2000, 2004).

Does Rho-kinase link PKG activity to $\mathrm{PIP}_{2}$ synthesis in the presynaptic terminal? We addressed this question using membrane capacitance measurements at calyx of Held presynaptic terminals in rat brainstem slices, together with quantitative mass spectrometry and ELISA assays of $\mathrm{PIP}_{2}$ content in brainstem synaptosomes. Our results have revealed a physiological role of Rhokinase in the homeostatic control of synaptic vesicle recycling, by linking PKG activity to presynaptic PIP $_{2}$ levels.

\section{Materials and Methods}

All experiments were performed in accordance with guidelines of the Physiological Society of Japan and animal experiment regulations at the Okinawa Institute of Science and Technology Graduate University.

Materials. The Rho-kinase inhibitor, trans-4-[(1R)-1-aminoethyl]$N$-4-pyridinylcyclohexanecar boxamide dihydrochloride (Y27632) and 1- $\alpha$-phosphatidylinositol 4,5-diphosphate sodium salt from bovine brain $\left(\mathrm{PIP}_{2}\right)$ were obtained from Sigma-Aldrich. L- $\alpha$-Phosphatidylinositol-4phosphate ammonium salt from porcine brain (PIP) was purchased from Avanti Polar Lipids. The PKG inhibitor guanosine $3^{\prime}, 5^{\prime}$-cyclic monophosphorothioate, $\beta$-phenyl-1, $\mathrm{N}^{2}$-etheno-8-bromo-, Rp-Isomer, sodium salt (Rp-cGMPS) was from Calbiochem. Cytotoxic necrotizing factor (CNF) catalytic domain-derived protein Rho activator II was from Cytoskeleton. A mouse monoclonal anti-PIP 2 antibody was from Abcam.

Biochemistry. For synaptosome isolation and phospholipid extraction, brainstems were isolated from postnatal day (P) 13-15 Wistar rats of either sex killed by decapitation under halothane anesthesia. After isolation, brainstem tissues were incubated with or without drugs for 5, 15, or
$60 \mathrm{~min}$ at $37^{\circ} \mathrm{C}$ in artificial CSF (aCSF) containing the following (in $\mathrm{mm}$ ): $125 \mathrm{NaCl}, 2.5 \mathrm{KCl}, 1 \mathrm{MgCl}_{2}, 2 \mathrm{CaCl}_{2}, 10$ glucose, 3 myo-inositol, 2 sodium pyruvate, 0.5 ascorbic acid, $1.25 \mathrm{NaH}_{2} \mathrm{PO}_{4}, 26 \mathrm{NaHCO}_{3}(310-315$ mOsm, pH 7.3, when saturated with $\left.95 \% \mathrm{O}_{2} / 5 \% \mathrm{CO}_{2}\right)$. Synaptosomes were isolated as described previously (Villasana et al., 2006). Briefly, tissues were homogenized in $0.32 \mathrm{~m}$ sucrose, $4 \mathrm{~mm}$ HEPES-NaOH buffer ( $\mathrm{pH} 7.3 \mathrm{kept}$ at $<4^{\circ} \mathrm{C}$ ), supplemented with EDTA-free Protease Inhibitor Cocktail (Roche), Phosphatase Inhibitor Cocktail 3 (Sigma-Aldrich), and kinase inhibitor sodium orthovanadate (Sigma-Aldrich). Filtered homogenates were then clarified by 15 min centrifugations at $10,200 \times \mathrm{g}$. To extract acidic phosphatidyl lipids, an ice-cold methanol/chloroform/ $\mathrm{HCl} 12 \mathrm{~N}(80 / 40 / 1)$ mixture was added to the remaining tissue pellets, vortexed thoroughly, and centrifuged at $1,500 \mathrm{rpm}$ for $5 \mathrm{~min}$. A chloroform/0.1N-HCl (1/2) nonpolar/polar solvent mixture was added to create a phase split to separate lipids from water-soluble constituents. Phospholipids were collected and evaporated using a vacuum centrifuge (Concentrator 5301, Eppendorf). For quantification of PIP $_{2}$ by ELISA, lipid samples were dissolved in PBS containing the $\mathrm{PIP}_{2}$ sensor provided in the $\mathrm{PI}(4,5) \mathrm{P}_{2}$ Mass ELISA kit (K-4500, Echelon). $\mathrm{PIP}_{2}$ content in each sample was then quantified following the manufacturer's instructions. Luminometric analyses were performed by measuring the final signal absorbance at $450 \mathrm{~nm}$ using a microplate reader (Benchmark Plus 1706930J1, Bio-Rad). PIP 2 levels were normalized to the wet weight of brainstem tissue. For quantification of inositol phospholipids by mass spectrometry, lipids samples were diluted with isopropanol/acetonitrile $(60 / 40, v / v)$. After mixing $10 \mu \mathrm{l}$ of diluted sample with $10 \mu \mathrm{l}$ of 9-aminoacridine hemihydrate matrix (Acros Organics), prepared at 10 $\mathrm{mg} / \mathrm{ml}$ dissolved in isopropanol/acetonitrile, $0.5 \mu \mathrm{l}$ of the mixture was spotted on a MALDI Opti-TOF stainless steel plate (Applied Biosystems). MALDI-ToF MS and MS/MS analyses were performed using a QSTAR Elite QqTOF mass spectrometer, equipped with a $1 \mathrm{kHz} \mathrm{Nd}$ / YAG pulsed laser (355 nm) and an electrostatic mirror (Applied Biosys- 

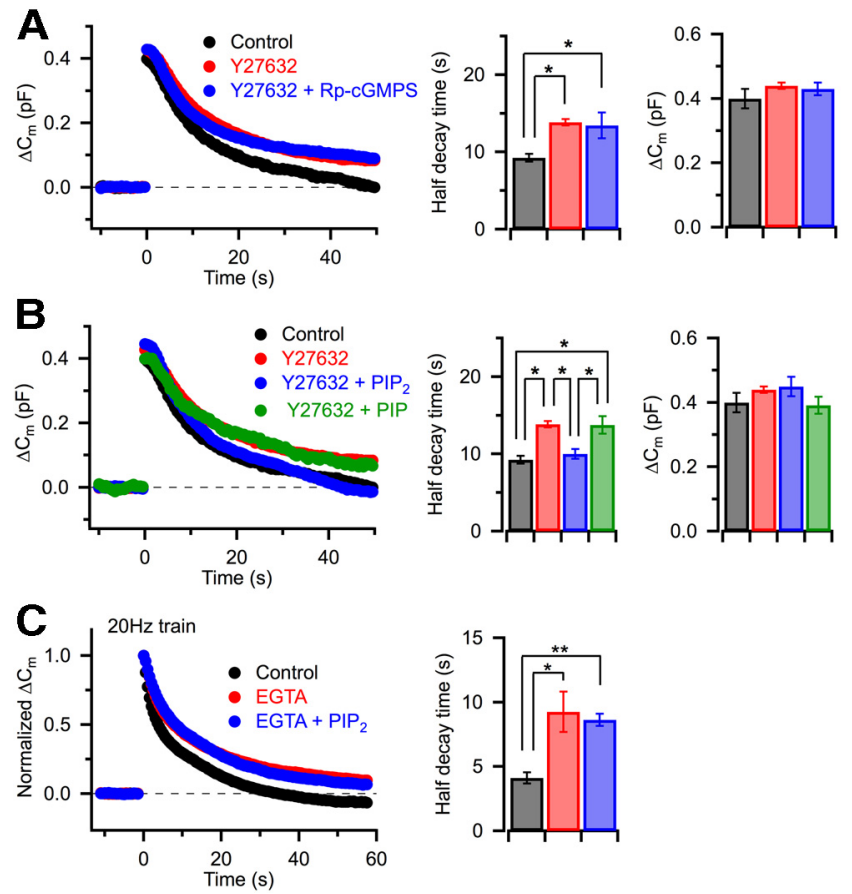

Figure 2. Rho-kinase inhibitor slowed vesicle endocytosis via the PKG/PIP 2 pathway in calyx of Held synapses. Membrane capacitance $\left(C_{m}\right)$ change evoked by a $20 \mathrm{~ms}$ depolarizing pulse (from -80 to $\left.+10 \mathrm{mV}\right)$. $\boldsymbol{A}$, Direct injection of Y27632 $(10 \mu \mathrm{M})$ into calyceal terminals (red trace and bars) significantly slowed endocytosis. The effect of coloading Y27632 and Rp-cGMPS ( $3 \mu \mathrm{M})$ (blue) into calyces was indistinguishable from the effect of $\mathrm{Y} 27632$ alone (red). The averaged traces of $C_{m}$ records are derived from 6-10 terminals. Summary bar graphs of $Y 27632$ effect on endocytic half-decay time, magnitudes of exocytic $C_{m}$ change $\left(\Delta C_{m}\right)$, and $\mathrm{Ca}^{2+}$ current amplitude $\left(\mathrm{I}_{\mathrm{Ca}}\right) \cdot \boldsymbol{B}, \mathrm{PIP}_{2}(5 \mu \mathrm{m})$, when coloaded with $\mathrm{Y} 27632$, rescued the slowing effect of the latter (blue trace, superimposed). Bar graphs are the same as in $\boldsymbol{A}$. In contrast, PIP $(5 \mu \mathrm{m})$ had no such effect (green). $\boldsymbol{C}, C_{m}$ changes induced by a train of $20 \mathrm{~ms}$ depolarizing pulses ( 20 times) at $20 \mathrm{~Hz}$ in the presence of $0.5 \mathrm{~mm}$ EGTA (control, black), $10 \mathrm{~mm}$ EGTA (red), or $10 \mathrm{~mm}$ EGTA and $5 \mu \mathrm{M}$ PIP 2 (blue) coloaded into P13-P14 calyceal terminals. Traces are averaged $C_{m}$ records derived from $6-10$ terminals, normalized at the peak. Bar graphs represent endocytic half-decay times. ${ }^{*} p<0.05 .{ }^{* *} p<0.01$.

tems). Data were acquired in negative ion reflectron mode at an accelerating potential of $-15 \mathrm{kV}$. Phospholipids spectra and signal-tonoise ratios were determined using Analyst QS 2.0 software (Applied Biosystems). Integrated areas of lipid peaks were corrected against peak areas of internal standards (giving a response ratio for each lipid) and normalized to an external standard, phosphatidylglycerol, PG (18:0/ 18:0) added during the lipid extraction procedure (Avanti Polar Lipids). For purification of anti-PIP 2 antibody, sodium azide and newborn calf serum were removed using the Antibody Purification Kit Protein A (Abcam) according to the manufacturer's instructions.

Electrophysiology. Methods for preparing auditory brainstem slices, containing the medial nuclei of trapezoid bodies from Wistar rats (P13P15), have been described previously (Yamashita et al., 2010; Eguchi et al., 2012). Briefly, rats were killed by decapitation under halothane anesthesia. Before recording, brainstem slices were incubated at $37^{\circ} \mathrm{C}$ for $1 \mathrm{~h}$ in aCSF. Membrane capacitance measurements were made from calyx of Held presynaptic terminals in whole-cell configuration at $26-27^{\circ} \mathrm{C}$ (Yamashita et al., 2010; Eguchi et al., 2012). For recordings, aCSF contained $10 \mathrm{~mm}$ tetraethylammonium chloride, $0.5 \mathrm{~mm} 4$-aminopyridine, $1 \mu \mathrm{M}$ tetrodotoxin, $10 \mu \mathrm{M}$ bicuculline methiodide, and $0.5 \mu \mathrm{M}$ strychnine hydrochloride. The pipette solution contained $118 \mathrm{~mm}$ Cs gluconate, $30 \mathrm{~mm} \mathrm{CsCl,} 10$ mм HEPES, 0.5 mм EGTA, 1 mм $\mathrm{MgCl}_{2}$, 12 mm disodium phosphocreatine, $3 \mathrm{~mm}$ Mg-ATP, and 0.3 mm Na-GTP ( $\mathrm{pH}$ 7.3-7.4 adjusted with $\mathrm{CsOH}$, 315-320 mOsm). Data were acquired at a sampling rate of $100 \mathrm{kHz}$, using an EPC-10 patch-clamp amplifier controlled by PatchMaster software (HEKA Elektronik) after on-line filtering at $5 \mathrm{kHz}$. Calyceal terminals were voltageclamped at a holding potential of $-80 \mathrm{mV}$, and single-step depolarization (to $+10 \mathrm{mV}, 20 \mathrm{~ms}$ ) was used for inducing presynaptic $\mathrm{Ca}^{2+}$ currents $\left(\mathrm{I}_{\mathrm{Ca}}\right)$. Drugs were infused from whole-cell pipettes into calyceal terminals by diffusion. Care was taken to maintain access resistance $<14 \mathrm{M} \Omega$ to allow diffusion of drugs into the terminal within 4 min after membrane rupture. Data
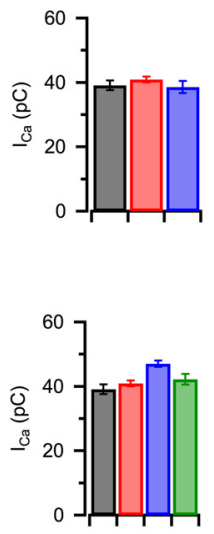

were analyzed using IGOR Pro 6 (WaveMetrics). All values are given as mean \pm SEM. Differences were considered statistically significant at $p<$ 0.05 in Student's unpaired $t$ test or ANOVA with Tukey ad hoc test.

\section{Results \\ Downregulatory effect of a Rho-kinase inhibitor on $\mathrm{PIP}_{2}$ content in \\ brainstem synaptosomes}

The $\mathrm{PIP}_{2}$ level in brainstem tissue and at calyces of Held of rats after hearing onset can be reduced by application of an NO scavenger or a PKG inhibitor (Eguchi et al., 2012). To test whether Rho-kinase is involved in this signaling pathway, we examined the $\mathrm{PIP}_{2}$ level in brainstem synaptosomes after application of the Rhokinase-specific inhibitor Y27632 (Uehata et al., 1997) using ELISA and mass spectrometry. Incubation of brainstem synaptosomes with Y27632 $(4 \mu \mathrm{M})$ for $15 \mathrm{~min}$ at $37^{\circ} \mathrm{C}$ reduced the $\mathrm{PIP}_{2}$ content by twofold to threefold in ELISA (Fig. 1A) and mass spectrometry (Fig. 1B) assays. Likewise, the PKG inhibitor Rp-cGMPS ( $3 \mu \mathrm{M})$ incubated with brainstem synaptosomes for $15 \mathrm{~min}$ at $37^{\circ} \mathrm{C}$, reduced the $\mathrm{PIP}_{2}$ content in ELISA (Fig. 1A) and mass spectrometric assays (Fig. $1 B$ ), as previously reported for ELISA experiments of brainstem tissue extracts (Eguchi et al., 2012). Coapplication of Y27632 (4 $\mu \mathrm{M})$ and Rp-cGMPS (3 $\mu \mathrm{M})$ did not further reduce the $\mathrm{PIP}_{2}$ content (Fig. $1 A, B$ ), suggesting that PKG and Rho-kinase operate in series in a signaling pathway upregulating $\mathrm{PIP}_{2}$. The inhibitory effect of Y27632 was surprisingly selective for $\mathrm{PIP}_{2}(1045 \mathrm{Da})$, with little effect on the levels of the precursors phosphatidylinositol (PI) (885 Da), phosphatidylinositol-mono-phosphate (PIP) (965 Da), or the downstream product phosphatidylinositol-tri-phosphate $\left(\mathrm{PIP}_{3}\right)$ $(1125 \mathrm{Da})$ in tandem mass spectrometry analysis (Fig. 1C,D; see below for discussions).

\section{Inhibitory effect of Rho-kinase inhibitor on vesicle} endocytosis at the calyx of Held presynaptic terminal

At calyces of Held of developing rats, the expression of PKG increases, and PKG accelerates vesicle endocytosis through a $\mathrm{PIP}_{2}$-dependent mechanism after hearing onset (Eguchi et al., 2012). To test whether Rho-kinase might be involved in this mechanism, we loaded Y27632 $(10 \mu \mathrm{M})$ directly into calyceal terminals from whole-cell patch pipettes (Fig. $2 A, B$ ). Depolarizing pulses (from -80 to $+10 \mathrm{mV}$ ) of $20 \mathrm{~ms}$ duration induced an exocytic $\Delta \mathrm{C}_{\mathrm{m}}$ jump of $\sim 0.4 \mathrm{pF}$, followed by a slower endocytic decay, with a half-time $\left(\tau_{0.5}\right)$ of $9.25 \pm 0.51 \mathrm{~s}(n=6)$. Y27632 loading significantly slowed the endocytic $\tau_{0.5}$ to $13.9 \pm 0.42 \mathrm{~s}$ $(n=10)$, with no effect on the exocytic $\Delta \mathrm{C}_{\mathrm{m}}$ amplitude or $\mathrm{I}_{\mathrm{Ca}}$ (Fig. 2A,B).

As in biochemical assays (Fig. 1), coloading of Rp-cGMPS (3 $\mu \mathrm{M})$ and Y27632 $(10 \mu \mathrm{M})$ into calyces had no greater effect than their individual loadings on the endocytic $\tau_{0.5}(13.5 \pm 1.67 \mathrm{~s}, n=$ 10) (Fig. 2A), suggesting that Rho-kinase operates downstream from $\mathrm{PKG}$ in the same pathway, rather than in a parallel pathway. 
Unlike bath-applied Rho-kinase inhibitor at hippoglossal synapses (GonzálezForero et al., 2012), Y27632 directly loaded into the calyx presynaptic terminal had no effect on $\Delta \mathrm{C}_{\mathrm{m}}$ or $\mathrm{Ca}^{2+}$ currents $\left(\mathrm{I}_{\mathrm{Ca}}\right)$ associated with transmitter release (Fig. 2A).

The slowing effect of the Rho-kinase inhibitor on vesicle endocytosis was reversed by coapplication of $\mathrm{PIP}_{2}(5 \mu \mathrm{M})$ into calyceal terminals (Fig. $2 B$ ), suggesting that a reduction in endogenous $\mathrm{PIP}_{2}$ by the Rho-kinase inhibitor could be rescued by exogenous $\mathrm{PIP}_{2}$ loading into presynaptic terminals. By contrast, intraterminal loading of the $\mathrm{PIP}_{2}$ precursor PIP together with Y27632 had no effect, suggesting that the latter inhibited PIP5K for the production of $\mathrm{PIP}_{2}$ from PIP. Furthermore, $\mathrm{PIP}_{2}$ loading had no effect on vesicle endocytosis slowed by the $\mathrm{Ca}^{2+}$ chelator EGTA (10 mM) (Yamashita et al., 2010), suggesting that it has no general rescuing effect on the rate of vesicle endocytosis (Fig. 2C). These results, together with no effect of loading $\mathrm{PIP}_{2}$ alone on endocytic rate (Eguchi et al., 2012), suggest that exogenous $\mathrm{PIP}_{2}$ can be incorporated into an endocytic accelerating mechanism downstream of Rho-kinase cascade, only when endogenous $\mathrm{PIP}_{2}$ level declines, thereby rescuing the endocytic rate of synaptic vesicles (see below).

\section{Rho-kinase activator counteracted the negative regulatory effects of PKG inhibitor on the $\mathrm{PIP}_{2}$ level in brainstem synaptosomes and on the rate of vesicle endocytosis}

We next examined the effect of activating Rho-kinase using the cytotoxic necrotizing factor (CNF)-derived peptide Rho activator II (Flatau et al., 1997). Incubation of brainstem synaptosomes with Rho activator II $\left(5 \mu \mathrm{g} / \mathrm{ml}, 15 \mathrm{~min}\right.$ at $\left.37^{\circ} \mathrm{C}\right)$ significantly increased the synaptosomal $\mathrm{PIP}_{2}$ content and counteracted the inhibitory effect of the PKG inhibitor, Rp-cGMPS (3 $\mu \mathrm{M}$ ), in ELISA (Fig. 3A) and tandem mass spectrometric assays (Fig. $3 B$ ). These results, together with those of the Rho-kinase inhibitor (Fig. 1), strongly suggest that Rhokinase mediates the upregulatory effect of PKG on the $\mathrm{PIP}_{2}$ level in the brainstem.

Rho activator II $(5 \mu \mathrm{g} / \mathrm{ml})$, when coloaded with Rp-cGMPS into the calyx of Held presynaptic terminal, rescued the slowing effect of the PKG inhibitor on vesicle endocytosis $(8.0 \pm 0.5 \mathrm{~s}, n=4)$ (Fig. 4A). Rho activator II, when loaded alone, had no significant effect on endocytic rate $(8.2 \pm 0.4 \mathrm{~s}, n=7)$, like single $\mathrm{PIP}_{2}$ loading (Eguchi et al., 2012), suggesting that endogenous $\mathrm{PIP}_{2}$ is close to a saturating level in normal presynaptic terminal membrane. Neither the exocytic $\Delta \mathrm{C}_{\mathrm{m}}$ nor $\mathrm{I}_{\mathrm{Ca}}$ was affected by the Rho activator (Fig. $4 A$ ). These results suggest that presynaptic Rhokinase accelerates vesicle endocytosis, operating downstream from the NO/PKG signal cascade.
B

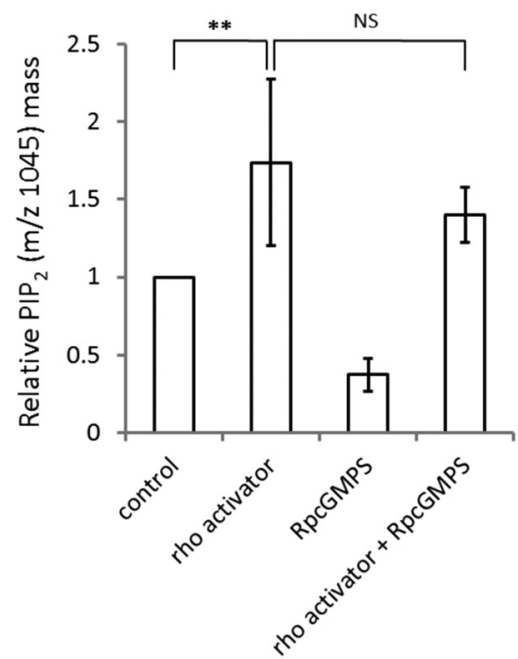

Figure 3. Rho activator increased $\mathrm{PIP}_{2}$ level and rescued the effect of the PKG inhibitor. Assessment of $\mathrm{PIP}_{2}$ level in brainstem synaptosomes by ELISA $(\boldsymbol{A})$ and tandem mass spectrometry $(\boldsymbol{B})$. Treatment of brainstem tissue with Rho activator II (CNF derived) $\left(5 \mu \mathrm{g} / \mathrm{ml}\right.$ ) for $15 \mathrm{~min}$ at $37^{\circ} \mathrm{C}$, significantly increased the PIP content of synaptosomes. Bathing the tissue with Rho activator
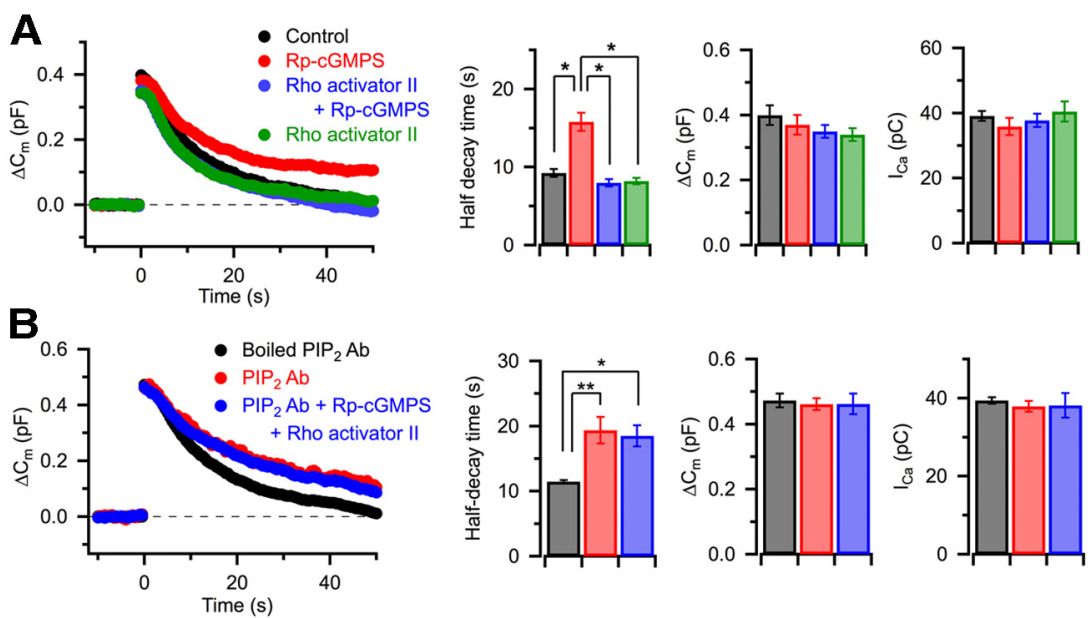

Figure 4. Rho activator II reversed the slowing effect of PKG inhibitor on vesicle endocytosis via increasing PIP ${ }_{2}$ level. $\boldsymbol{A}_{\text {, }}$ Intraterminal loading of Rho activator II (CNF derived) $(5 \mu \mathrm{g} / \mathrm{ml})$ into calyceal terminals had no effect on endocytosis (green trace and bars). Coloading of Rho activator II with Rp-cGMPS (3 $\mu \mathrm{M}$ ) reversed (blue) the inhibitory effect of Rp-cGMPS (red) on endocytosis. Data are from $6-10$ calyces. $\boldsymbol{B}$, Anti-PIP antibody ( $20 \mu \mathrm{g} / \mathrm{ml}$, red trace and bars) loaded into the presynaptic terminals significantly slowed endocytic $C_{m}$ changes, whereas boiled anti-PIP ${ }_{2}$ antibody $(20 \mu \mathrm{g} / \mathrm{ml}$, black) had no effect. In the presence of anti-PIP 2 antibody, Rho activator II no longer rescued the inhibitory effect of Rp-cGMPS (blue). Data are from $4-6$ calyces.

To examine whether the rescuing effect of the Rho activator on endocytic rate is indeed mediated by endogenous $\mathrm{PIP}_{2}$ production, we loaded anti-PIP $\mathrm{P}_{2}$ antibody into calyceal terminals. This antibody, when loaded alone, slowed vesicle endocytosis $(19.4 \pm 2.1 \mathrm{~s}, n=5)$, whereas boiled antibody had no effect, suggesting that the antibody reduced available $\mathrm{PIP}_{2}$ (Fig. $4 B$ ). In the presence of anti-PIP ${ }_{2}$ antibody in presynaptic terminals, the Rho activator no longer rescued the endocytic rate slowed by Rp-cGMPS (18.5 \pm 1.6 s, $n=4$ ) (Fig. $4 B$ ).

\section{Discussion}

In the present study, inhibition of Rho-kinase activity with Y27632 specifically decreased PIP $_{2}$ content in the synaptosomal fraction of brainstem tissue and slowed the time course of vesicle endocytosis recorded using capacitance measurements at calyces 
of Held presynaptic terminals. In contrast, enhancement of Rhokinase activity with Rho activator II increased synaptosomal $\mathrm{PIP}_{2}$ levels and counteracted the slowing effect of the PKG inhibitor on vesicle endocytosis. When vesicle endocytosis is slowed, replenishment of releasable vesicles through recycling is retarded. This distorts the fidelity of synaptic transmission, particularly in response to prolonged high-frequency inputs (Eguchi et al., 2012). In this respect, Rho-kinase plays a key role in the molecular cascade providing homeostatic control of high-frequency information transfer through neuronal circuits. This cascade operates when postsynaptic NMDA receptors are activated by glutamate released from presynaptic terminals and accelerates endocytosis via $\mathrm{PIP}_{2}$ production, in an activity-dependent manner, according to the magnitude of exocytosis, thereby coupling vesicle recycling with neuronal activity (Micheva et al., 2003; Eguchi et al., 2012). The retrograde linkage from postsynaptic NMDA receptors to presynaptic $\mathrm{PKG}$ is mediated by NO, but the linkage from $\mathrm{PKG}$ to $\mathrm{PIP}_{2}$ in presynaptic terminals remained elusive (Micheva et al., 2003; Eguchi et al., 2012). In this study, we have shown that Rho-kinase mediates the molecular cascade from PKG to PIP 2 . Although the present study was conducted at room temperature $\left(26-27^{\circ} \mathrm{C}\right)$, endocytic rate is faster at physiological temperature by a factor of $>1.4$ (Fernandez-Alfonso and Ryan, 2004; Micheva and Smith, 2005; Renden and von Gersdorff, 2007). Likewise, at physiological temperature, activities of various kinases and NMDA receptors (Steinert et al., 2010) involved in this retrograde cascade are higher. Thus, this exoendocytic coupling mechanism would operate more efficiently for the maintenance of high-fidelity, high-frequency synaptic transmission in vivo.

PKG directly binds to the GTPase RhoA (Kato et al., 2012) and negatively controls Rho-kinase activity for vascular smooth muscle contraction (Sauzeau et al., 2000; Sandu et al., 2001; Kato et al., 2012) and stress fiber formation (Sawada et al., 2001). In contrast, PKG can positively control RhoA expression (Sauzeau et al., 2003; Rolli-Derkinderen et al., 2005) and Rho-kinase activity possibly via phosphorylation of RhoGEF17 (Lutz et al., 2013). The downstream effector, Rhokinase, also binds to and activates PIP5K (Weernink et al., 2000, 2004; Yang et al., 2004), which produces PIP 2 through phosphorylation of PIP. Thus, the upregulatory effect of the RhoA activator on the $\mathrm{PIP}_{2}$ content of brainstem synaptosomes (Fig. 3) is likely mediated by activation of PIP5K. Although Rho-kinase might also increase the availability of PIP to the PIP5 kinase (Yamamoto et al., 2001), intraterminal loading of PIP did not rescue the slowing effect of Rho-kinase inhibitor on vesicle endocytosis unlike $\mathrm{PIP}_{2}$ loading (Fig. $2 B$ ), suggesting that PIP5K is likely the main target of Rho-kinase in the nerve terminal. Our phospholipids mass spectrometry analyses have shown that the Rho-kinase inhibitor Y27632 specifically lowers the $\mathrm{PIP}_{2}$ content in brainstem synaptosomes with little effect on the PIP content (Fig. 1C,D). These results are consistent with reports that the main locus of cellular PIP is in the Golgi membrane of cells (Wang et al., 2003) and that the PIP pool in the plasma membrane contributes little to de novo $\mathrm{PIP}_{2}$ synthesis (Hammond et al., 2012).

In conclusion, we have elucidated a novel physiological function of Rho-kinase, which positively controls synaptic vesicle endocytosis by upregulating plasma membrane $\mathrm{PIP}_{2}$. This function is linked via the retrograde signal cascade of NO and PKG that is essential for maintenance of high-fidelity synaptic transmission in the CNS.

\section{References}

Bito H, Furuyashiki T, Ishihara H, Shibasaki Y, Ohashi K, Mizuno K, Maekawa M, Ishizaki T, Narumiya S (2000) A critical role for a Rhoassociated kinase, p160ROCK, in determining axon outgrowth in mammalian CNS neurons. Neuron 26:431-441. CrossRef Medline

Cremona O, Di Paolo G, Wenk MR, Lüthi A, Kim WT, Takei K, Daniell L, Nemoto Y, Shears SB, Flavell RA, McCormick DA, De Camilli P (1999) Essential role of phosphoinositide metabolism in synaptic vesicle recycling. Cell 99:179-188. CrossRef Medline

Dittman J, Ryan TA (2009) Molecular circuitry of endocytosis at nerve terminals. Annu Rev Cell Dev Biol 25:133-160. CrossRef Medline

Eguchi K, Nakanishi S, Takagi H, Taoufiq Z, Takahashi T (2012) Maturation of a PKG-dependent retrograde mechanism for exoendocytic coupling of synaptic vesicles. Neuron 74:517-529. CrossRef Medline

Fernández-Alfonso T, Ryan TA (2004) The kinetics of synaptic vesicle pool depletion at CNS synaptic terminals. Neuron 41:943-953. CrossRef Medline

Flatau G, Lemichez E, Gauthier M, Chardin P, Paris S, Fiorentini C, Boquet P (1997) Toxin-induced activation of the G protein $\mathrm{p} 21$ Rho by deamidation of glutamine. Nature 387:729-733. CrossRef Medline

González-Forero D, Montero F, García-Morales V, Domínguez G, GómezPerez L, García-Verdugo JM, Moreno-López B (2012) Endogenous Rho-kinase signaling maintains synaptic strength by stabilizing the size of the readily releasable pool of synaptic vesicles. J Neurosci 32:68-84. CrossRef Medline

Granseth B, Odermatt B, Royle SJ, Lagnado L (2006) Clathrin-mediated endocytosis is the dominant mechanism of vesicle retrieval at hippocampal synapses. Neuron 51:773-786. CrossRef Medline

Hammond GR, Fischer MJ, Anderson KE, Holdich J, Koteci A, Balla T, Irvine RF (2012) PI4P and PI $(4,5) \mathrm{P}_{2}$ are essential but independent lipid determinants of membrane identity. Science 337:727-730. CrossRef Medline

Haucke V, Neher E, Sigrist SJ (2011) Protein scaffolds in the coupling of synaptic exocytosis and endocytosis. Nat Rev Neurosci 12:127-138. CrossRef Medline

Itoh T, Koshiba S, Kigawa T, Kikuchi A, Yokoyama S, Takenawa T (2001) Role of the ENTH domain in phosphatidylinositol-4,5-bisphosphate binding and endocytosis. Science 291:1047-1051. CrossRef Medline

Jost M, Simpson F, Kavran JM, Lemmon MA, Schmid SL (1998) Phosphatidylinositol-4,5-bisphosphate is required for endocytic coated vesicle formation. Curr Biol 8:1399-1402. CrossRef Medline

Jung N, Haucke V (2007) Clathrin-mediated endocytosis at synapses. Traffic 8:1129-1136. CrossRef Medline

Kato M, Blanton R, Wang GR, Judson TJ, Abe Y, Myoishi M, Karas RH, Mendelsohn ME (2012) Direct binding and regulation of RhoA protein by cyclic GMP-dependent protein kinase I $\alpha$. J Biol Chem 287:4134241351. CrossRef Medline

Lutz S, Mohl M, Rauch J, Weber P, Wieland T (2013) RhoGEF17, a Rhospecific guanine nucleotide exchange factor activated by phosphorylation via cyclic GMP-dependent kinase I $\alpha$. Cell Signal 25:630-638. CrossRef Medline

McPherson PS, Garcia EP, Slepnev VI, David C, Zhang X, Grabs D, Sossin WS, Bauerfeind R, Nemoto Y, De Camilli P (1996) A presynaptic inositol-5-phosphatase. Nature 379:353-357. CrossRef Medline

Micheva KD, Smith SJ (2005) Strong effects of subphysiological temperature on the function and plasticity of mammalian presynaptic terminals. J Neurosci 25:7481-7488. CrossRef Medline

Micheva KD, Buchanan J, Holz RW, Smith SJ (2003) Retrograde regulation of synaptic vesicle endocytosis and recycling. Nat Neurosci 6:925-932. CrossRef Medline

Mueller BK, Mack H, Teusch N (2005) Rho kinase, a promising drug target for neurological disorders. Nat Rev Drug Discov 4:387-398. CrossRef Medline

Nakayama AY, Harms MB, Luo L (2000) Small GTPases Rac and Rho in the maintenance of dendritic spines and branches in hippocampal pyramidal neurons. J Neurosci 20:5329-5338. Medline

Ota KT, Monsey MS, Wu MS, Schafe GE (2010) Synaptic plasticity and NO-cGMP-PKG signaling regulate pre- and postsynaptic alterations at rat lateral amygdala synapses following fear conditioning. PloS One 5:e11236. CrossRef Medline

Renden R, von Gersdorff H (2007) Synaptic vesicle endocytosis at a CNS nerve terminal: faster kinetics at physiological temperatures and increased 
endocytosis capacity during maturation. J Neurophysiol 98:3349-3359. CrossRef Medline

Riento K, Ridley AJ (2003) Rocks: multifunctional kinases in cell behaviour. Nat Rev Mol Cell Biol 4:446-456. CrossRef Medline

Rolli-Derkinderen M, Sauzeau V, Boyer L, Lemichez E, Baron C, Henrion D, Loirand G, Pacaud P (2005) Phosphorylation of serine 188 protects RhoA from ubiquitin/proteasome-mediated degradation in vascular smooth muscle cells. Circ Res 96:1152-1160. CrossRef Medline

Royle SJ, Lagnado L (2010) Clathrin-mediated endocytosis at the synaptic terminal: bridging the gap between physiology and molecules. Traffic 11:1489-1497. CrossRef Medline

Sandu OA, Ito M, Begum N (2001) Selected contribution: insulin utilizes NO/cGMP pathway to activate myosin phosphatase via Rho inhibition in vascular smooth muscle. J Appl Physiol 91:1475-1482. Medline

Sauzeau V, Le Jeune H, Cario-Toumaniantz C, Smolenski A, Lohmann SM, Bertoglio J, Chardin P, Pacaud P, Loirand G (2000) Cyclic GMPdependent protein kinase signaling pathway inhibits RhoA-induced $\mathrm{Ca}^{2+}$ sensitization of contraction in vascular smooth muscle. J Biol Chem 275:21722-21729. CrossRef Medline

Sauzeau V, Rolli-Derkinderen M, Marionneau C, Loirand G, Pacaud P (2003) RhoA expression is controlled by nitric oxide through cGMPdependent protein kinase activation. J Biol Chem 278:9472-9480. CrossRef Medline

Sawada N, Itoh H, Yamashita J, Doi K, Inoue M, Masatsugu K, Fukunaga Y, Sakaguchi S, Sone M, Yamahara K, Yurugi T, Nakao K (2001) cGMPdependent protein kinase phosphorylates and inactivates RhoA. Biochem Biophys Res Commun 280:798-805. CrossRef Medline

Schweizer FE, Ryan TA (2006) The synaptic vesicle: cycle of exocytosis and endocytosis. Curr Opin Neurobiol 16:298-304. CrossRef Medline

Shibasaki Y, Ishihara H, Kizuki N, Asano T, Oka Y, Yazaki Y (1997) Massive actin polymerization induced by phosphatidylinositol-4-phosphate 5-kinase in vivo. J Biol Chem 272:7578-7581. CrossRef Medline

Steinert JR, Postlethwaite M, Jordan MD, Chernova T, Robinson SW, Forsythe ID (2010) NMDAR-mediated EPSCs are maintained and accelerate in time course during maturation of mouse and rat auditory brainstem in vitro. J Physiol 588:447-463. CrossRef Medline

Sunico CR, González-Forero D, Domínguez G, García-Verdugo JM,
Moreno-López B (2010) Nitric oxide induces pathological synapse loss by a protein kinase G-, Rho kinase-dependent mechanism preceded by myosin light chain phosphorylation. J Neurosci 30:973-984. CrossRef Medline

Uehata M, Ishizaki T, Satoh H, Ono T, Kawahara T, Morishita T, Tamakawa H, Yamagami K, Inui J, Maekawa M, Narumiya S (1997) Calcium sensitization of smooth muscle mediated by a Rho-associated protein kinase in hypertension. Nature 389:990-994. CrossRef Medline

Villasana LE, Klann E, Tejada-Simon MV (2006) Rapid isolation of synaptoneurosomes and postsynaptic densities from adult mouse hippocampus. J Neurosci Methods 158:30-36. CrossRef Medline

Wang YJ, Wang J, Sun HQ, Martinez M, Sun YX, Macia E, Kirchhausen T, Albanesi JP, Roth MG, Yin HL (2003) Phosphatidylinositol 4 phosphate regulates targeting of clathrin adaptor AP-1 complexes to the Golgi. Cell 114:299-310. CrossRef Medline

Weernink PAO, Schulte P, Guo Y, Wetzel J, Amano M, Kaibuchi K, Haverland S, Voss M, Schmidt M, Mayr GW, Jakobs KH (2000) Stimulation of phosphatidylinositol-4-phosphate 5-kinase by Rho-kinase. J Biol Chem 275:10168-10174. CrossRef Medline

Weernink PAO, Meletiadis $\mathrm{K}$, Hommeltenberg S, Hinz M, Ishihara $\mathrm{H}$, Schmidt M, Jakobs KH (2004) Activation of type I phosphatidylinositol 4-phosphate 5-kinase isoforms by the Rho GTPases, RhoA, Rac1, and Cdc42. J Biol Chem 279:7840-7849. CrossRef Medline

Yamamoto M, Hilgemann DH, Feng S, Bito H, Ishihara H, Shibasaki Y, Yin HL (2001) Phosphatidylinositol 4,5-biphosphate induces actin stressfiber formation and inhibits membrane ruffling in CV1 cells. J Cell Biol 152:867-876. CrossRef Medline

Yamashita T, Eguchi K, Saitoh N, von Gersdorff H, Takahashi T (2010) Developmental shift to a mechanism of synaptic vesicle endocytosis requiring nanodomain $\mathrm{Ca}^{2+}$. Nat Neurosci 13:838-844. CrossRef Medline

Yang SA, Carpenter CL, Abrams CS (2004) Rho and Rho-kinase mediate thrombin-induced phosphatidylinositol 4-phosphate 5-kinase trafficking in platelets. J Biol Chem 279:42331-42336. CrossRef Medline

Zheng J, Cahill SM, Lemmon MA, Fushman D, Schlessinger J, Cowburn D (1996) Identification of the binding site for acidic phospholipids on the PH domain of dynamin: implications for stimulation of GTPase activity. J Mol Biol 255:14-21. CrossRef Medline 